\title{
A Picture of Istanbul through the Eyes of Women Writers from Turkey
}

\author{
Gül Deniz Demirel Aydemir
}

\begin{abstract}
Women have their own miscellaneous ways of experiencing and perceiving the world, and telling their stories from those perspectives. Therefore, women writers are gaining more and more recognition all over the world and specifically in Turkey as well. This article aims to compare the stories in the collection, titled Istanbul in Women's Short Stories, in terms of employing women's perspective while drawing a picture of the city as the inhabitants of a metropolis. The article comes up with the finding that in most of the stories, ideas of changing dynamics in Istanbul and masculine traits of the city are prominent as the common observations.
\end{abstract}

Index Terms-Change, city, Istanbul, masculinity, short story, Turkey, women writers.

\section{INTRODUCTION}

Istanbul has been a great source of inspiration for many people so far and women writers in Turkey use this source of inspiration well. Hande Ögüt noticed this fact and decided to gather short stories from 27 different women writers in Turkey and presented them in a compilation under the title, Istanbul in Women's Short Stories. Harte claims "Taken together, the stories are like a map of Turkey's female literary terrain, encapsulating the authors' range of style and subject matter from the tragic to the comic, the contemplative to the action-driven" [1]. This article aims to present two most prominent aspects of Istanbul presented in Istanbul in Women's Short Stories, namely the changing dynamics in the city and the masculine attributions of the city.

\section{Changing DynAmics IN IstANBUL}

The most conspicuous aspect of Istanbul seen in Istanbul in Women's Short Stories is the change that the city has been going through in the last half-century. Sometime after the Turkish Republic had been established, industrial growth created many job opportunities in Istanbul and with the growth of population, Istanbul attracted lots of immigrants from rural areas in Anatolia so the change is observed on four layers. The face of the city has remarkably altered in terms of its appearance, denizens, pace of life, and relationships. Of course, this change is not for the better but for the worse. Past beauties are almost always presented in comparison with the present ugliness or ferocity of the city.

To start with the change in the appearance of Istanbul, in the story, "A Brief Sadness", a mother takes her daughter to

Manuscript received September 21, 2014; revised November 23, 2014. Gül Deniz Demirel Aydemir is with the Hacettepe University, Ankar, Turkey (e-mail: gdenizd@hacettepe.edu.tr). a location that remains unaffected by the change. She says "I wanted to show you this place ... one of the rare spots that witnessed the Istanbul before it expanded so drastically" [2] and the daughter finds the place very relaxing. All the blessings are attributed to Istanbul of the past in the stories.

Similarly, in "City of Borders", the narrator cannot find the past beauties in their places: "I should [have] gone to the places I went when I was a young girl in Yakac1k, to the sea gardens, where the Judas trees start taking on their color towards summer; but once again I hadn't. Each time, I always found I was somewhere other than that tea garden. Istanbul's borders were constantly expanding [3]. Expanding borders take the memories of good old days away. In the same story, expansion process is illustrated by mentioning hotel constructions as well: "Hotels that would change the city's silhouette were under construction on the European side opposite" [3]. However, the narrator is hopeful that the city will not give in for good: "None of the skyscraper hotels under construction on the other side could completely change or close off the familiar view of the Bosphorus" [3]. The next story seems to hint that it is just a bit of wishful thinking.

In İrepoğlu's "The Bostanc1 Garden Tree", a sycamore tree, which used to be considered to be in an "exclusive" and "classy" [4] part of Istanbul, dies because the garden it is in becomes a city property due to rezoning and municipality lays cobblestones around it. The tree cannot reach to enough soil and it cannot take nourishment. Before it dies, its branches tries to "stretch upward in order to see the sea" [4] but it does not help because "it was no longer possible to see the sea, blocked as it was by grim buildings" [4]. The expansion takes the life out of the living entities and also out of the beautiful atmosphere as suggested in the following statements as well: "Is it this place, gone forever, where now only block after block of apartment buildings rise... ?" [4]. Old residents of the city cannot recognize their favorite places due to the changes in the city. Moreover, they anticipate some further changes in the city for the future by mentioning the possibility of branches of newly planted trees meeting the branches of an old tree "[i]f only the street stays where it is" [4]. She actually thinks that it will not be possible in reality.

In "An Ode to My Istanbul", the same idea of natural beauties being replaced by construction works is present: "When did someone allow those trees to be replaced by the concrete apartment blocks that so brutally broke one of the chains binding me to Boğaziçi?" [5]. People living in the city lose their sense of belonging because of the changing face of the city. Past beauties of Istanbul are described in order to strengthen the effect of the brutal change, which the narrator experiences, on the readers. The narrator 
remembers the pleasant taste of the "tiny, crimson strawberries which, once eaten, left such a sublime taste on the palate" [5] and grown in Arnavutköy, Istanbul. She points out that those beauties are already lost due to the expansion in the city: "The soil that once produced strawberries was already being concreted over" [5] and she resents it. Also, years ago, an old woman growing those strawberries anticipates what happens later on. She says "After I die, my children will build huge concrete blocks on that fertile land and these delicious strawberries will disappear for good, I know" [5]. She underscores the inevitability of this process. The narrator clarifies that this alteration is a change for the worse: "You, my Istanbul, are gradually losing the struggle" [5]. Actually, Istanbul resists it because the word, struggle, calls for a resistance.

Besides the hotel and factory constructions that contribute to the man-made ugliness of Istanbul mentioned in the stories above, 'Gecekondu houses' are another factor brought about by expansion presented in Baydar's story, "Remembering a City". These houses are small constructions built in a very short time at night in the dark because the owners do not have a land of their own. They build them on a location that belongs to the city municipality and they do not obtain any official permit from the municipality. As their locations and designs are not planned professionally, they make the city look ugly and in chaos. Baydar describes them as the following: "Gecekondu houses really were impoverished huts built over a night around newly established factories" [6]. They are built around factories because people migrating from rural areas mostly work in factories. This point takes us to the second aspect of the changes in Istanbul that is the change in its denizens.

In many stories a yearning for the past is seen in people from different ethnic and religious backgrounds living in peace in Istanbul. However, when it comes to present tense, the expressions of Istanbulites are marked by an obvious hostility towards immigrants coming from the southeastern parts of Turkey. What's more, emergence of 'others' is underlined in stories relating to the contemporary Istanbul.

Three stories point to the changing inhabitants of the city directly. The narrator in "The Bostanc1 Garden Tree" suggests that "[t]he changes in the city had silently accompanied the changes in its residents" [4]. Similarly, in "Dilan", her aunt introduces the city to Dilan, a girl who has just arrived from Mardin, a southeastern city: "The other side of the street is Beyoğlu, Dilan. Beyoğlu and what's left of Beys is only a stone's throw away" [7], she says. 'Bey' means a man from a rich family with good manners in Turkish and she complains that those respectable people do not live in Istanbul anymore. Also, in "Remembering a City", there is a reference to the same idea: "As the city changed secretly from within, simultaneously changing its inhabitants, we failed to notice this change together with the change in ourselves. We lived the city just the way we lived life; rowdily, with the blunt recklessness of youth" [6]. Here, the narrator implies that people living in Istanbul were not really able to adapt to the changes and they could not embrace the changing inhabitants of the city. In fact, the people who have lived in Istanbul from the past days up to present time change their attitudes towards the diversity in the city.

In "An Ode to my Istanbul", the narrator refers to good old days when the children named "Ayşe, Necmettin, Sabahattin, Laki, Dimitri, Seta, Aram, and Ester..." [5] used to play outside talking to each other in Turkish, Greek, Spanish and Armenian. She also mentions that this atmosphere used to make them very happy and proud: "You used to look rather enviously at their affectionate attachments and friendships, which paid no heed to religion, language or race... At that time you prided yourself on out multifaith culture, the ezan blending with church bells" [5]. The peace in the city makes Istanbul a cosmopolitan city in the past.

Nevertheless, the cosmopolitan nature in the present time is not heartily welcomed. One can hear people making fun of a different race nowadays. In Samanc1's story, "In the Melancholy of Wisteria", it is put to words neatly by the following sentences of an immigrant: "Istanbul absorbs all sounds. A flowing river, wild pansies, an ethnic joke... I scatter them like a string of pearls on the hard surface of my memory" [8]. These kinds of instances of hostility leave serious traces in people's memories.

In her story, "City of Borders", Cihan Aktaş portrays more serious acts of hostility towards immigrants and criticizes this situation by creating a character who can recklessly say “Ah, Istanbul, Istanbul, we can't walk your streets anymore because of those southeastern hicks" [3]. As clearly seen, her tone is humiliating. She continues: "You need good manners to live in this city, if you immigrate here you need to do something before you deserve to live in one of the world's most beautiful cities, like take a six month or one-year course; our esteemed ancestors kept a spittoon nearby on their walking routes" [3]. She considers immigrants as a threat to her elite life and she wants to impose her own life style on those people by comparing them to the elite people of Istanbul in the past. However, it is not only the Istanbulites who are disappointed. Immigrants are also disappointed as suggested in "Dilan" through the words heard in the bus terminal: "Is this Istanbul, is this really Istanbul? This wasn't the city I saw on TV. We came here with such big dreams" [7]. They expect a better life when they plan to immigrate to Istanbul but what they see on TV is not the reality.

Another phenomenon related to the habitants brought about by the change and population growth is creation of 'others' in the city. When the population is so high and the range is diverse, others are blamed for any unpleasant phenomena. People start disliking them. Tarlabaş1 is a poor gecekondu area where mostly the others live and Sancak depicts it well:

Fast and dark-skinned Senegalese roll hastily down the Sakızağacı slope. A sad old homosexual who hasn't been on the job for a while now... A boy with a pocketknife in his hand, musing. And aging of glue sniffers and outcasts that dwell in the night... In other words, these are the 'others' [7].

Immigrants, queers, addicts and people living on the street are the others in Istanbul. Also there are Gypsies as pointed out in the same story. Gypsies are made others by the same woman calling the southeastern immigrants 'hicks': "I never buy flowers from Gypsies, I know what they do to 
keep those looking do fresh, they have buckets full of dirty water somewhere" [7].

All these examples illustrate the feeling of unrest among people living in Istanbul but coming from different backgrounds, having different life styles or actually some of whom have no choice but to comply with low standards of life in Istanbul due to the physical changes accompanied by the process of a change in terms of inhabitants of the city. Nevertheless, these people, one way or the other, live together. Ramazanoğlu puts it clearly in her story, "Anemone Flower": "The diversity of this city makes people find ways of getting along with each other" [9].

In addition to its appearance and inhabitants, industrialization and expansion in the city changes the city life in Istanbul. The book starts with a depiction of chaos in the city. The first story in the compilation, "Music of the Ox Horn", illustrates a cross-section from the modern city life in Istanbul: "It was crowded, chaotic. Because of all the pushing, nobody could get anywhere. Everyone was being spun around, as if they were in a whirlpool. The faces in the crowd were sullen" [10]. The chaos described is a result of the fast pace of life in the city. Sometimes the fast life in the city becomes unbearable for its citizens: "I was watching the hurried steps of all those people with their telephones to their ears and their synchronized arms, and I felt I might suffocate" [8]. What's more, this chaos creates a sound which is likened to that of a huge machine in "A Brief Sadness": "The uniform mumble consisting of hundreds of sounds of the giant machine that crushed human beings..." [2]. Voices of individuals are lost in the crowd and they turn into notes contributing to the mumble. The same idea of creating a unified sound is a dramatic element of the story, "Mi Hatice". Hatice is a woman who is a victim of arranged marriage and she tries to find her own note or identity amongst the continuous mumble of the others creating chaos in the city: "Hatice started to imagine what kind of sound would emerge if each of these passengers were a single musical note. It would be chaotic and noisy to begin with; then the notes would exchange places, and after that the individual sounds would fade away: an ever-diminishing melody" [11]. In all this chaos, individual loses its importance and starts to be ignored or lost so sometimes it turns into an indifference towards one another in the society. It is pointed out in the following words of Atasü: "Exhaust fumes, gases that hills of garbage spewed out, drowning out the noises of humans, the whimpering of the sick, the sobs of the abandoned... Who ever hears the cries of a starving baby or the sighs of those with no future" [2].

The idea of indifference caused by the ferocity of modern city life finds voice in other stories as well. However, this time it is not only the descriptions of the city by narrators but also experiences of characters in the stories that are related. The one in Alanyalı's story wanders in a bazaar and complains that nobody would pay attention if she needed help and she says "Nobody took heed of me. They were in such a bustle that even had I fainted nobody would have stopped to lend a helping hand" [10]. Similarly, in "An-bulist", the narrator is in trouble and even though there is somebody nearby, he does not bother to help her: "I was stuck, with dogs, with dogs all around me, a constantly ringing phone in my pocket and a package of meat in my hand. I shouted for help. There was a grey-haired man on the other side of the road. He just watched. Nobody else came to my aid" [12].

In Aykol's story, "Bayan Naciye House", indifference is shown from the other perspective. This time the words of the indifferent person are reported. In this story, narrator is a woman from an intellectual background and she is not interested in the bitter experiences of her neighbor who tries to tell the story of how she lost her husband and left alone with two children. The narrator makes it clear that she does not want to share the suffering of the other woman by saying to herself "I couldn't have cared less, but I listened all the same" [13]. She cannot sympathize with her because she really does not know what a woman from a lower socioeconomic background may go through in the life in a big city like Istanbul. This idea is clearly stated in "An-bul-ist", too: "Istanbul is like a country within itself. Not just because it is large, but because the people in all its different quarters know nothing about each other or how they live" [12].

At this point a comparison with the past is possible on these grounds as well. In the past, people in Istanbul used to feel more responsibility towards one another and also towards the other living beings and one would not be wellregarded unless she or he cares about others. Karakaş touches upon it in her story, "Mihr, Mahr, Mihrimah": "This place used to be more modern than any spot in Europe. Slaves had their rights and the birds their nests. If you did not have a garden for birds, two small bowls for dogs, you wouldn't be strolling in the streets with your head held high and humanity in your hands" [14]. However, in present time, the situation is not like that. Indifference is completely internalized.

Indifference is not seen only among strangers. Even the closest relationships such as the ones in families and couples receive their shares of it in Istanbul. In "A Brief Sadness", the relationship of a mother and a daughter is explored in these terms. The mother meets her daughter to tell her about a very important decision of hers but she gives up the idea thinking that it will not really be a big issue for her daughter amongst the rush of trivialities of city life. The daughter asks if she is ill or not and the mother speculates about it in her mind: "Is her concern really for my health, or is it merely the fear of having to fit the burden of my illness into her busy life already crammed as full as a storeroom?" [2]. The mother cannot believe in the sincerity of the question but she can figure out the grounds for her daughter's attitude and describes it aptly:

Her daughter worked too hard, her son-in-law worked too hard. All young people worked too hard; to make a certain group of invisible people wealthier. They didn't know what they were working for. The thought they were working for a 'good' life. 'Good' meant 'prosperous' in their vocabulary. The gaps in meaning between words had been erased in their fast lives. In reality they weren't working for a more prosperous life, in reality... Their lives seemed as smooth and clear as a straight line drawn with a ruler, but the line was nothing but a tightrope... [2].

The mother actually knows that most people do not have time for many serious issues because they are convinced by the reality imposed upon them by modern city life. Towards 
the end of the story she reminds her daughter that she loved her more than anything in the world and the daughter is touched by her words but the mother knows that her feelings will not last long: "As soon as she was back at work, her daughter would forget this brief sadness; in fact, perhaps even before that... before parting from the view of the redbud slope" [2]. Modern city life changes the priorities of people.

These kinds of relationships inside the family are mentioned in other stories as well. In 'Tubbynanna's Istanbul", there is an old couple living in Istanbul. The husband dies one day and the wife decides to call her "ungrateful daughter" [15] to help her handle the situation. Later in the story, another daughter's ungratefulness is demonstrated: "She hadn't knocked on her door for nearly three months" [15]. They do not see each other for a long time even though they live in the same city. Also, in "Anemone Flower", a mother mentions her son's alienation to his family due to the city's destructive features: "My precious son, always tetchy and rebellious, wanted to get as far as possible from us. He couldn't wait to be devoured by the city" [9].

Apart from parent-children relationships, alienation forced by the modern city life is observed in marriages, too. Spouses cannot spend time together because of their busy lives and when they have the chance, whether they carry the traces of city life on them or they are interested in other things. In "Bayan Naciye House", a divorced couple comes together again and they start to live together believing that they can make it this time. However, their busy lives do not make it possible. This is observed even by the neighbors: "Your husband's never at home, he must be very busy, said Hanife Hanım meaningfully" [13]. When he comes, he cannot be a part of the home life carrying the smell of the city inside: "I buried my nose in his shoulder, inhaling a mixture of smells: earth, exhaust fumes, coal" [13]. Alternatively, he comes home but he does not really communicate with his partner: "He's not coming home. He's not going to take his pillow into the living room and sleep on the sofa" [13]. His existence does not create a difference at home. Another similar example can be found in "Anemone Flower". The husband in this story is interested more in the outer world than his home: "That evening my dear husband had come home early. He was buried in his newspaper, which interested him more than I did" [9]. The relationships in Istanbul are changing day by day in parallelism with the changes in the city's appearance, its habitants, and the atmosphere of the city life.

\section{Masculine Traits OF Istanbul}

The second point to deal with is the gender of Istanbul as a city. In other words, it's being a city with masculine attributions and lives of women in the city are going to be discussed in this part. In her review, Julia Harte claims that "Istanbul is almost always portrayed in these stories as a male lover". To start with, the expression in the last paragraph of Söğüt's story, "Why I Killed Myself in Istanbul", makes it clear that the writer sees Istanbul as a man and this man is just like one of those men living in
Istanbul described above: "This city has been a man for centuries and doesn't know how to love women" [16]. This story examines the embodiment of "hundreds and thousands of forms of womanhood" [16] in one woman so it enables the reader to peep in through the windows of many woman living in Istanbul. The narrator remarks that she decided to kill herself in this city because women in Istanbul die because of many different reasons. It is really a dangerous city even for the women who do not risk anything I their lives: "In the quietest neighborhood, in an ordinary apartment in a most ordinary building, with my ordinary husband and ordinary children. Even if I did lead a truly ordinary life, my red, blonde, black, brown hair would dangle down the window and danger would climb up my hair" [16]. These dangers are actually fatal ones: "One day I'm stabbed in the heart with jealousy, the next day I stab my husband in the heart" [16]. The narrator suggests that it is in fact related to poverty as well "Poverty is deemed to smell of death" [16]. Then, she mentions other types who suffer in the city such as a woman giving birth to many children but having to let some on streets, a woman working in a hair salon, serving to rich woman and is filled with rage against them day by day, a woman selling her body to strangers out on streets, a tiny girl being forced by her mother to beg for money on the streets, a married, pregnant teenager who is left alone by her husband and cannot turn back to her home because of being afraid of her father murdering her, a woman giving birth to her baby alone at home and whose baby is thrown out by her husband, a woman stealing handbags, a drug-smuggler woman, and a jailed woman fantasizing over bombing the city and giving an end to all these atrocities in the city. All these examples show that the city does not have any space for women to experience their identities. It is a man and it cannot embrace women, mostly women from lower class.

The idea of lack of space for women in the city is physically visible as well. Alanyalı depicts it well: "Women are so few, the square was reserved solely for men. Wait, I told myself, you will surely find a place for yourself in this city. Before long the whirlpool pulled me in as well." [10]. She also wanted to hang on to the city but it did not let her. The streets secured for men are full of men like Ulviye Hanım's sons in "Break of Dawn in Tarlabaşı": "Ulviye Hanım's sons, strut about heatedly, engorged with testosterone to the bursting point. They are ready to break up fights, to put out fires, to die for the sake of the women they have fallen for, to kill for them" [17]. Women are just like a piece of decoration in their lives and their fights are with men again. So, it's just a world of men for men.

Suffering of women is observable in plots of the stories as well. For instance, one of those men who can die or kill for the sake of women they love fights the boyfriend of 17years-old version of his girlfriend in a dream over who made her unhappier in Eray's story, "The Button to Activate Forgetting" [18]. Another one of them in Çokum's story kills Kanite, a resident of Tarlabaşı. She actually guesses her end talking of her ex-lover, a "drunk paranoid thug who obsesses over her" [17] even before she is killed and she says "One day he is going to kill me" [17].

While Istanbul is portrayed as a man in most stories, 
other cities in the southestern parts of Turkey are considered to be women in "Dilan". They are just like the women in Istanbul experiencing the brutalities of the male city. "Nusaybin, Silopi, Cizre, Şırnak are all women, women like remote, deserted cities; women who are shot dead by a stray bullet when pregnant or while resting on a balcony" [7]. The writer establishes a gender correspondence for other cities because of their resemblance to what women in Istanbul go through.

In "Mi Hatice", a woman who is married to a man whom she did not choose herself and she is disgusted by. She dies metaphoric deaths everyday when she is with him. She does not have any freedom. She has to be escorted by her husband even when she is turning back home from work. One day her husband is a bit late to meet her after work and Hatice feels relieved instead of worried: "Hatice had a strange feeling of being abandoned. This didn't upset her though; on the contrary, it relieved her somewhat, making her feel as if the burden she was carrying had become a little lighter" [11]. However, she is so strongly coded by the patriarchy that she even feels guilty because of her feelings: "Yet, all these feelings in turn disturbed Hatice..." [11]. When they are in train sitting side by side, she is happy that her husband never talks to her because she is ashamed of people realizing her to be his wife. When her husband, Sacit, has a heart attack and dies when sleeping in the train, she just steps out of the train as if nothing happened. This time she feels a bit guilty again: "As Hatice walked along the platform towards the exit, all the notes coalesced, forming a knot in her throat. Instinctively, she reached up to her throat. Undid her knot" [11]. However this time she frees herself from those feelings and feels for the first time that she is free: "The scarf on her head slid slowly down from her shoulders and cascaded to the floor. Leaving the scarf behind, she walked on calmly and vanished into the streets of Menekşe" [11]. The scarf in the story symbolizes the oppression of patriarchal society on woman. She leaves the scarf behind just like she does her husband and experiences her identity without her husband casting shadow over it: "All of a sudden, Hatice becomes a flawless, faultless 'mi' note" [11]. The notes actually symbolize the voices of the individuals in the mumbling sound in the city and before her husband's death Hatice thinks of herself as a mi note which is never comes out clearly from the flute. When she get rids of the patriarchal figure in her life, she can get a clearer sound and she finds her true identity.

Turning back to depicting the city as a male lover, Aykol's story "Bayan Naciye House" dwells on the idea of Bosphorus being a male lover to the women living near it in an eerie way. In her review, Harte summarizes the idea as the following: "the narrator moves into a new apartment whose other residents slyly educate her about the mystical 'men who come from the Bosphorus', like benevolent incubi, to pleasure the women who live on the shore". The neighbors try to convince the narrator that the Bosphorus men exist: "Why do you think it's only women who move to the Bosphorus?" [13]. Those men are depicted as the following: "Their hearts are no bigger than the nail on my little finger. . . . He needs to smell the sea air to stay alive. But not any sea, it must be Bosphorus". "They never age, they're never born and never die" [13] and they never show themselves to anyone except for their lovers. They are most likely to be mere fantasy. What pleasures woman is actually the Bosphorus itself. Therefore, the city is actually a man pleasuring woman if not tormenting them just like in the other stories. The city also has a symbolic male feature as well. In Topal's story, "The Silence of Sevinç Duman”, the narrator makes a contribution to the idea from a psychoanalytic aspect: "When I woke up each day, the first thing I saw was the Galata Tower, rising before my eyes like a giant phallus" [19].

\section{CONCLUSION}

All in all, Istanbul in Women's Short Stories is a very useful book to observe the process of change in Istanbul. This change is seen in four different layers. The first type of change is visible in the silhouette of the city. Natural beauties in the city are replaced by concrete blocks and the wonderful view of the sea is not perfectly visible anymore. The second change is in terms of the habitants of the city. With the growth of population in Istanbul, the elite people of the city are replaced mostly by immigrants coming from different parts of Anatolia and this brought about the third change that is the alteration in the receiving of the cosmopolitan atmosphere by the city's inhabitants compared to the past. The last change is the changing pace of life in Istanbul and its reflections on human relationships causing lack of communication. Apart from the process of change in Istanbul, book provides material to dwell on Istanbul's representation as a male domain that denies the identification of women with itself. It is there as a male lover mostly to torture women but sometimes to please the well-off ones as well. These are the most striking aspects of Istanbul in the stories.

\section{REFERENCES}

[1] J. Harte. (2012). Short stack. Time out Istanbul. [Online]. Available: http://www.timeoutistanbul.com/en/books/article/2525/Short-stack

[2] E. Atasü, "A brief sadness," in Istanbul in Women's Short Stories, H. Ögüt, Ed. West Sussex: Milet, 2012, pp. 47-52.

[3] C. Aktaş, "City of Borders," in Istanbul in Women's Short Stories, H. Öğüt, Ed. West Sussex: Milet, 2012, pp. 201-221.

[4] G. İrepoğlu, "The Bostanc1 garden tree," in Istanbul in Women's Short Stories, H. Öğ̈̈t, Ed. West Sussex: Milet, 2012, pp. 231-239.

[5] S. Aciman, "An ode to my Istanbul," in Istanbul in Women's Short Stories, H. Öğüt, Ed. West Sussex: Milet, 2012, pp. 311-321.

[6] O. Baydar, "Remembering a city," in Istanbul in Women's Short Stories, H. Öğüt, Ed. West Sussex: Milet, 2012, pp. 337-342.

[7] J. Sancak, "Dilan," in Istanbul in Women's Short Stories, H. Öğüt, Ed. West Sussex: Milet, 2012, pp. 255-261.

[8] S. Samanc1, "In the melancholy of Wisteria," in Istanbul in Women's Short Stories, H. Öğüt, Ed. West Sussex: Milet, 2012, pp. 149-155.

[9] Y. Ramazanoğlu, “Anemone flower," in Istanbul in Women's Short Stories, H. Öğüt, Ed. West Sussex: Milet, 2012, pp. 285-300.

[10] B. Alanyal1, "The music of the Ox Horn," in Istanbul in Women's Short Stories, H. Öğüt, Ed. West Sussex: Milet, 2012, pp. 1-9.

[11] G. Boralığlu, "Mi Hatice," in Istanbul in Women's Short Stories, H. Öğüt, Ed. West Sussex: Milet, 2012, pp. 63-70.

[12] K. Karakaşl1, “An-bul-ist.," in Istanbul in Women's Short Stories, H. Öğ̈̈t, Ed. West Sussex: Milet, 2012, pp. 71-90.

[13] E. Aykol, "Bayan Naciye house," in Istanbul in Women's Short Stories, H. Öğüt, Ed. West Sussex: Milet, 2012, pp. 11-45.

[14] B. Karakaş, "Mihr, Mahr, Mihrimah," in Istanbul in Women's Short Stories, H. Öğüt, Ed. West Sussex: Milet, 2012, pp. 305-310.

[15] G. Kivilcim, "Tubbynanna's Istanbul," in Istanbul in Women's Short Stories, H. Öğüt, Ed. West Sussex: Milet, 2012, pp. 127-136. 
[16] M. Söğüt, "Why I killed myself in Istanbul," in Istanbul in Women's Short Stories, H. Öğ̈̈t, Ed. West Sussex: Milet, 2012, pp. 301-304.

[17] S. Çokum, "Break of dawn in Tarlabaşı," in Istanbul in Women's Short Stories, H. Öğüt, Ed. West Sussex: Milet, 2012, pp. 53-62.

[18] N. Eray, "The button to activate forgetting," in Istanbul in Women's Short Stories, H. Öğ̈̈t, Ed. West Sussex: Milet, 2012, pp. 137-147.

[19] S. Topal, "The silence of Sevinç Duman," in Istanbul in Women's Short Stories, H. Öğ̈̈t, Ed. West Sussex: Milet, 2012, pp. 107-118.

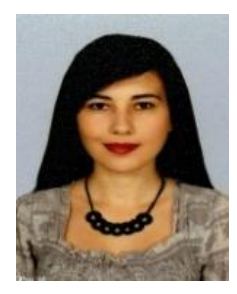

Gül Deniz Demirel Aydemir was born in Afyonkarahisar, Turkey in 1988. She got a B.A. degree in English language teaching from Middle East Teachnical University, Ankara, Turkey in 2009. She is currently doing an M.A. degree in English literature at the same university.

She has been working as an English language instructor at Hacettepe University, School of Foreign Languages, Ankara since 2010. Previously, she worked as a language assistant in Immenhofer Schule, Stuttgart, Germany in 2010. Teaching English as a second language, English literature, and Turkish literature are among her research interests. 